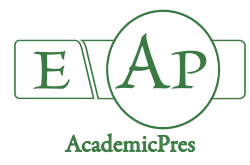

\title{
Biohardening of Arabidopsis thaliana Seeds and Seedlings with Fraser Photinia Associated Bacterium (PGB_invit) in In vitro Conditions
}

\author{
Maria BATOOL, Özlem AKKAYA, Mine GÜL ŞEKER, \\ Yelda ÖZDEN ÇİFTÇİ \\ Gebze Technical University, Faculty of Basic Sciences, Department of Molecular Biology and Genetics, 41400, Kocaeli, \\ Turkey; elizee_16@hotmail.com;ozlem@gtu.edu.tr; gul@gtu.edu.tr; ozden@gtu.edu.tr ( ${ }^{*}$ corresponding author)
}

\begin{abstract}
The aim of this study was to analyze possible positive effects of putatively endophytic PGPB (PGB_invit), which was isolated from long-term in vitro cultured fraser photinia microshoots, on seed and 7-day old seedling stages of Arabidopsis thaliana. Seeds and in vitro-germinated seedlings were inoculated with $10^{7} \mathrm{CFU} / \mathrm{mL}$ and $10^{8} \mathrm{CFU} / \mathrm{mL}$ active (A) and inactive (I) endophytic bacterial populations along with their mix compositions $(A+I)$ and suspended in MPYE broth together with their controls (untreated ones). 14 days old seedlings were evaluated for various plant growth parameters [i.e., shoot and root fresh weight $(\mathrm{FW})$, shoot length (SL), shoot and root dry weight (DW), root length (RL) and photosynthetic pigments including chlorophyll $a, b$ and carotenoids of plantlets] as well as endophytic and rhizospheric trait of bacteria. Positive effects of inactive and active bacterium on FW, DW and photosynthetic pigments for 7-day inoculated seedlings were recorded whereas an increase in photosynthetic contents for seed stage inoculations was observed. Rhizospheric and endophytic colonization of the bacteria was confirmed by PCR with the presence of virDl gene, which is previously recorded to be existed in the plasmid of bacterium after inoculation (Şeker et al., 2017). Overall, these results demonstrated that this peculiar putative endophytic bacterium being beneficial in active and even more useful in inactive form for $A$. thaliana when optimum conditions and concentrations are used. Moreover, presence of $\operatorname{virDl}$ gene suggested its potential possibility to be used in bioengineering along with various other beneficial PGPR features as biofertilizer.
\end{abstract}

Keywords: Arabidopsis thaliana; endophytic bacteria; plant-bacteria interactions; virD1 gene

It is well-known that beneficial endophytic bacteria could promote plant growth and yield either directly by i.e., i) nitrogen fixation, ii) solubilization of phosphorus, iii) sequestering of iron by production of siderophores, iv) production of phytohormones such as auxins, cytokinins, gibberellins and v) lowering of ethylene concentration (Kloepper et al., 1989; Glick, 1995; Glick et al., 1999) or indirectly by i.e., i) antibiotic production, ii) synthesis of antifungal metabolites, iii) depletion of iron from the rhizosphere, iv) competition for colonization on roots, v) production of fungal cell wall lysing enzymes, and vi) induced systemic resistance (Weller and Cook, 1986; Dunne et al., 1993; Kloepper et al., 1988; Liu et al., 1995; Glick et al., 1999).

There are several variables that effect the plant endophytes such as the growth stage of plant, type of plant tissue analyzed, plant health, nutritional condition of soil including $\mathrm{pH}$ and moisture content, temperature, altitude etc. and sometimes even the type of plant under consideration (in case of testing one endophyte on another

Received: 11 Jan 2019. Received in revised form: 29 May 2019. Accepted: 31 May 2019. Published online: 19 Jun 2019. 
plant) (Hardoim et al., 2008). Therefore, in order to have more understanding about various types of endophytes found in a single plant and their associations with plant, it is important to carry out broad screening techniques initially in model plants such as $A$. thaliana. For instance, Poupin et al. (2013) studied the effects of the PGPR bacterial model Burkholderia phytofirmans PsJN on the whole life cycle of A. thaliana. Their studies revealed that at different physiological stages of plant, strain PsJN colonized the roots of $A$. thaliana both rhizospherically and endophytically while early ontogeny also showed increased several growth parameters and accelerated growth rate of the plants. Inoculations of $A$. thaliana with Paenibacillus yonginensis DCY84 (T) and Micrococcus yunnanensis PGPB7 indicated that $P$. yonginensis DCY84 ( $\mathrm{T}$ )-inoculated plants were more resistant to salinity, drought and heavy metal stresses than control plants (Sukweenadhi et al., 2015). A recent study also documented that PGPB strains Pseudomonas simiae, Chryseobacterium polytrichastri and Burkholderia ginsengiterrae co-inoculated with aluminum stressed $A$. thaliana were able to support the overall growth of plant by exhibiting plant growth promoting activities e.g. auxins and siderophores production and phosphate solubilization (Farh et al., 2017). Besides, some endophytic microbial contaminations in the plant tissue culture systems could also have beneficial influence on plant growth with supplying different additives and could have potential to use as bio-inoculants. Thus, isolation and characterization of these potential in vitro contaminants for production of biological compounds from plant cultures is becoming attractive for scientists. With this approach, our research group (Şeker et al., 2017) recently isolated a putatively endophytic bacterium (PGB_invit) that was detected in long-term in vitro cultured microshoots of fraser photonia. Phenotypical and biochemical properties of this bacterium, together with plant growth-promoting characteristics (PGPC) abilities including phytostimulation, biofertilization and hydrolytic activities, were determined and results showed that PGB_invit exhibited nitrogenfixing ability as well as indole-3-acetic acid (IAA) and gibberellic acid $\left(\mathrm{GA}_{3}\right)$ producing capability. Gram-negative putative endophytic bacterium showed similarity to uncultured bacteria and Rhizobiales according to $16 \mathrm{~S}$ rRNA sequencing and phylogenetic tree that was constructed by Neighbour Joining method. It is concluded that the bacterial strain with different PGPC can be considered as a beneficial microbe for the facilitation of fraser photinia growth. Thus, the aim of this study was to evaluate the possible interaction of PGB_invit with the model plant to determine whether this bacterium was i) host specific, ii) endophytic, iii) and had any beneficial effect on the two physiological stages of $A$. thaliana in vitro.

\section{Materials and Methods}

Plant material: Sterilization and in vitro seed germination Arabidopsis thaliana Columbia (Col-0) seeds were used for all of the experiments. Seeds were surface sterilized with
$70 \% \mathrm{v} / \mathrm{v} \mathrm{EtOH}$ for $1-2$ minutes followed by rinsing with $15 \% \mathrm{v} / \mathrm{v}$ bleach $(\mathrm{NaOCl})$ for 10 minutes and washing 3 times for 5 minutes each with sterile distilled water. Afterwards, seeds were transferred to Petri plates (10 seeds/Petri plate) containing 1/2 MS (Murashige and Skoog, 1962) semi-solid medium. For seed germination, all Petri plates containing seeds were pre-placed at $4{ }^{\circ} \mathrm{C}$ in dark for $\sim 3$ days to synchronize germination before transferring to plant growth chamber where Petri plates were kept vertically at $22^{\circ} \mathrm{C}$ with a photoperiod of $16 \mathrm{~h}$ of light $(3000$ lux) and $8 \mathrm{~h}$ of dark.

\section{Cultivation of putative bacterium}

The putatively endophytic bacterial strain, previously isolated and characterized from long-term in vitro cultured microshoots of fraser photinia (Photinia $\times$ fraseri Dress), was stored in glycerol at $-80{ }^{\circ} \mathrm{C}$ (Şeker et al., 2017). PGB invit was taken from $-80{ }^{\circ} \mathrm{C}$ and pre-cultured in MPYE broth medium for 5-7 days followed by culturing in $250 \mathrm{~mL}$ of flasks. After 7-10 days, serial dilutions (up to $10^{-6}$ ) of main culture were conducted in order to determine optimal concentration of bacterial inoculum.

\section{Inoculation of PGB_invit to seed and seedlings}

Two physiological stages of $A$. thaliana i.e. seeds stage and 7-day in vitro germinated seedlings stage, were inoculated with two different concentrations of active (A) PGB_invit, i.e. $10^{7} \mathrm{CFU} / \mathrm{mL}\left(10^{7}\right)$ and $10^{8} \mathrm{CFU} / \mathrm{mL}\left(10^{8}\right)$ using flood inoculation technique (Ishiga et al., 2011). To assess the effect of inactivated bacterium, inoculums of same concentrations were heat inactivated separately at $95^{\circ} \mathrm{C}$ for 20 minutes and named inactive (I) bacterium throughout the experiments. Moreover, A and I forms of bacterium were also tested together $(\mathrm{A}+\mathrm{I})$ at $10^{7}$ and $10^{8}$ concentrations for the possible effects on the two stages of A. thaliana. There were three replicate plates separately for each inoculum of bacterium along with a separate control. Plates were placed in plant growth chamber vertically at $22^{\circ} \mathrm{C}$ with a photoperiod of $16 \mathrm{~h}$ of light and $8 \mathrm{~h}$ of dark.

\section{Determination of influence of $P G B$ invit on A. thaliana}

Fourteen (14) days old seedlings of $A$. thaliana, inoculated with different concentrations and populations of bacteria, were assessed for various growth parameters such as fresh (shoot and root) weight (FW), dry (shoot and root) weight (DW), root length (RL), shoot length (SL), photosynthetic pigments i.e. chlorophyll $a(\mathrm{Chl}$ a), $b(\mathrm{Chl}$ b) and carotenoids (Car). FW, SL and RL of individual seedlings were measured on the same day, whereas for DW, seedlings were to be incubated at $65^{\circ} \mathrm{C}$ for at least 24 hours. For chlorophyll analysis, shoots were kept in acetone in $2 \mathrm{ml}$ Eppendorf tubes at $4{ }^{\circ} \mathrm{C}$ for at least 24 hours and later, photosynthetic pigment analysis was carried out according to Lichtenthaler and Buschmann (2001) for wavelengths of $661.6 \mathrm{~nm}, 644.8 \mathrm{~nm}$ and $470 \mathrm{~nm}$ for Chl a, Chl b and Car, respectively. Similar procedure was followed for both the physiological stages where seeds were inoculated for 14 days for germination stage while 7 day-in vitro germinated seedlings were co-cultured for 7 days for seedling stage. 
956

\section{Assessment of bacterial existence inside seedlings}

Various protocols were followed to evaluate endophytic and rhizospheric interaction of bacterium with plantlets. For endophytic interaction, surface sterilization of seedlings was carried out where randomly selected and named, endophytic active (E1), endophytic inactive (E2) and control (E3) seedlings from replicate plates, were separately weighed and suspended in $5 \%$ of hydrogen peroxide $\left(\mathrm{H}_{2} \mathrm{O}_{2}\right)$ for 3 minutes in order to decontaminate roots from any associated bacterium. Later, seedlings were rinsed with sterile distilled water 3 times for 5 minutes each and crushed in sterile mortar pestle each separately with $1 \mathrm{ml}$ of MPYE broth. This followed serial dilutions of crushed suspension from $10^{0}-10^{-4}$ in MPYE broth and $100 \mu \mathrm{l}$ of each suspension was spreaded on MPYE agar plates with two replicates each. A validity check for sterilization protocol was also performed by inoculating last sterilization water from surface sterilization procedure.

Seedlings were randomly selected from replicate plates and weighed separately for rhizospheric active bacteria (R1), rhizospheric inactive bacteria (R2) and control (R3). Later, weighed seedlings were suspended, each separately, in bacterial growth medium i.e. MPYE and vortexed for 2 minutes in order to shed any possible bacterium associated with rhizosphere. R1, R2 and R3 were vortexed in place of sterilized crushed plant and broth mixture and same procedure was followed as for endophytic evaluation. All plates were incubated at $30{ }^{\circ} \mathrm{C}$ until the colonies appeared (normally in 7 days) and examined under light microscope for preliminary identification of putative endophytic bacterium by Gram-staining.

\section{Plasmid DNA extraction}

To confirm that the bacterial colonies found on MPYE agar plates belonged to PGB_invit, plasmid DNA from both the endophytic and rhizospheric cultures were isolated using Macherey-Nagel Nucleospin ${ }^{\circ}$ Plasmid Extraction Kit. Concentration $(\mathrm{ng} / \mu \mathrm{l})$ of extracted plasmid DNA was measured on nanodrop and assayed by agarose gel analysis.

Verification of $P G B$ invit presence in $A$. thaliana by PCR

The presence of $A$. rhizogenes virDI gene in isolated PGB_invit was reported by Şah (2017). Thus, PCR amplification was conducted on plasmid DNAs isolated from both the endophytic and rhizospheric PGB invit cultures. Each amplification mixture contained 1X FIREpol' PCR Mastermix (12.5 mM of $\mathrm{MgCl}_{2}$ ), $0.2 \mu \mathrm{M}$ of each primer and $\sim 100 \mathrm{ng} / \mu \mathrm{l}$ of template DNA in a final volume of $20 \mu \mathrm{l}$. Following PCR conditions were optimized for the amplification of plasmid DNA: initial denaturation at $94^{\circ} \mathrm{C}$ for $5 \mathrm{~min}$., followed by 25 cycles of denaturation at $95^{\circ} \mathrm{C}$ for $30 \mathrm{~s}$, annealing for $30 \mathrm{~s}$ at $55^{\circ} \mathrm{C}$, and extension at $72^{\circ} \mathrm{C}$ for 1 min with an additional extension at $72^{\circ} \mathrm{C}$ for 7 min followed by a cool down and incubation at $4{ }^{\circ} \mathrm{C}$. Universal forward ATGTCGCAAGGCAGTAGGCCCACCT-3') reverse primers CTACAAGGCGTCTTTCAGCAGCGAGC-5') we used for virD1 amplification. All samples were run on a $1 \%$ agarose gel on gel electrophoresis system for 30 minutes at 80 volts where 1000bp plus DNA (24075 Sizer ${ }^{\mathrm{nw}}, 144 \mathrm{ng}$ / ul) was used as marker. Visualization was done using Gel Logic 200 Imaging system under UV light [Biotium Inc, Hayward CA, USA].

\section{Data collection and statistical analysis}

Each trial was done with at least 10 seeds/seedlings and the trials were repeated at least 3 times. Statistical analysis of $A$. thaliana growth parameters, subjected to different concentrations of putative endophytic bacterium, was carried out using LSD test. Significant error difference was $\mathrm{P} \leq 0.05$.

\section{Results}

\section{Effect of PGB_invit on in vitro seed germination}

Experiments showed $100 \%$ germination rate for PGBinvit inoculated seeds, which indicated that there was no detrimental effect of bacterium on seed germination. For seed stage bacterial inoculations, both A $10^{7}$ and $10^{8}$ concentrations resulted in a decrease in FW of seedlings while I inoculation at $10^{7}$ concentration showed statistically insignificant result in comparison to control (Table 1). However, when A and I form of bacterium were inoculated together, at both tested concentrations, the detrimental effect of the A form was not detected as the highest FW was obtained $(47.08 \mathrm{mg})$ with A+I for $10^{7}$. Similar effect was observed for DW too (Table 2). Moreover, no negative influence of bacterium in A form at $10^{7}$ could be seen in SL (Table 3) but a decrease was observed with an increase in bacterial concentration. For A+I form of bacterium, a gradual positive influence was detected in which $10^{8}$ resulted in the longest shoots $(0.61 \mathrm{~cm})$. In case of RL, no significant effect of bacterium was evident for any replicates (Table 4).

In case of photosynthetic pigments, a significant positive effect was observed for A form of both the bacterial concentrations as the highest $\mathrm{Chl} \mathrm{a}, \mathrm{Chl} \mathrm{b}$ and Car was calculated compared to control (Table 5). Application of neither I nor A+I showed any significant difference in photosynthetic pigments for both the concentrations, except for $\mathrm{A}+\mathrm{I} 10^{7}$.

Effect of PGB_invit on in vitro 7-day old seedling stage inoculation

In contrast to the effect of bacterium on seed stage inoculations, a beneficial influence of all bacterial populations, except $\mathrm{A} 10^{8}$, was observed in $\mathrm{FW}$ of in vitro 7 day old inoculated seedlings where the highest FW (96.08 $\mathrm{mg}$ ) was obtained from $\mathrm{A}+\mathrm{I}$ inoculation of bacterium at $10^{7}$ concentration (Table 1). Similar effect was witnessed in DW too (Table 2). The only detrimental effect was observed in SL where shortest shoots were observed $(0.20$ $\mathrm{cm}$ ), when I bacterium was applied at $10^{8}$, in comparison to the rest (Table 3). In contrast, positive effect of $\mathrm{A}+\mathrm{I}$ bacterial population at $10^{7} \mathrm{CFU} / \mathrm{mL}$ was seen in $\mathrm{RL}$ where the longest root $(8.67 \mathrm{~cm})$ was measured (Table 4, Fig. 1). Similar outcome was seen for $\mathrm{Chl}$ a and $\mathrm{Chl} b$ with $\mathrm{A} 10^{8}$ and I $10^{7}$ populations of the bacterium, respectively (Table 5). No significant effect on carotenoids was observed for any bacterial inoculation. 
Table 1. Influence of PGB_invit inoculation in different physiological stages on fresh weight (FW) of $A$. thaliana seedlings ${ }^{\mathrm{a}}$

\begin{tabular}{ccc}
\hline $\begin{array}{c}\text { Inoculation } \\
(\mathrm{CFU} / \mathrm{ml})\end{array}$ & $\begin{array}{c}\text { Germination Stage } \\
(\text { Mean } \pm \text { SE })^{d} \\
(\mathrm{mg})\end{array}$ & $\begin{array}{c}\text { Seedling Stage } \\
(\text { Mean } \pm \text { SE })^{\mathrm{d}} \\
(\mathrm{mg})\end{array}$ \\
\hline Control & $43.58 \pm 0.73 \mathrm{ab}$ & $58.00 \pm 2.01 \mathrm{c}$ \\
$10^{7} \mathrm{~A}^{\mathrm{c}}$ & $18.08 \pm 0.72 \mathrm{~d}$ & $71.67 \pm 2.99 \mathrm{bc}$ \\
$10^{8} \mathrm{~A}^{\mathrm{c}}$ & $14.67 \pm 0.60 \mathrm{~d}$ & $63.50 \pm 1.41 \mathrm{c}$ \\
$10^{7} \mathrm{I}^{\mathrm{c}}$ & $45.50 \pm 0.31 \mathrm{a}$ & $80.58 \pm 1.17 \mathrm{~b}$ \\
$10^{8} \mathrm{I}^{\mathrm{c}}$ & $33.08 \pm 0.76 \mathrm{c}$ & $79.25 \pm 2.31 \mathrm{~b}$ \\
$10^{7} \mathrm{~A}+\mathrm{I}^{\mathrm{c}}$ & $47.08 \pm 0.47 \mathrm{a}$ & $96.08 \pm 1.99 \mathrm{a}$ \\
$10^{8} \mathrm{~A}+\mathrm{I}^{\mathrm{c}}$ & $40.08 \pm 1.45 \mathrm{~b}$ & $80.75 \pm 2.17 \mathrm{~b}$ \\
\hline
\end{tabular}

${ }^{\bar{a}}$ The data were collected 7 or 14 days after inoculation for seedling stage and germination stage, respectively. Each trial was made with at least 10 seeds/seedlings and the trials were repeated at least 3 times.

b "Germination Stage" means that PBG_invit inoculation was made to surface sterilized seeds whereas "Seedling Stage" means that PBG_invit inoculation was made to 7 day-seedlings following in vitro germination.

cThe different letters following the means show the statistical difference compared to the LSD test following ANOVA ( $\mathrm{P} \leq 0.05)$. Difference was evaluated vertically.

${ }^{\mathrm{d}}$ Mean \pm Standard Error; ${ }^{\mathrm{c}} \mathrm{A}$ : active form of bacterium showed; I: inactive form of bacterium; A+I: active and inactive form of the bacterium.

Table 2. Influence of PGB_invit inoculation in different physiological stages on dry weight (DW) of $A$. thaliana seedlings ${ }^{\mathrm{a}}$

\begin{tabular}{|c|c|c|}
\hline $\begin{array}{c}\text { Inoculation } \\
(\mathrm{CFU} / \mathrm{ml})\end{array}$ & $\begin{array}{c}\text { Germination Stage } e^{\mathrm{b}, c} \\
(\mathrm{Mean} \pm \mathrm{SE})^{\mathrm{d}} \\
(\mathrm{mg})\end{array}$ & $\begin{array}{l}\text { Seedling Stage } e^{\mathrm{b}, c} \\
(\mathrm{Mean} \pm \mathrm{SE})^{d} \\
(\mathrm{mg})\end{array}$ \\
\hline Control & $2.56 \pm 0.05 a$ & $3.69 \pm 0.10 \mathrm{c}$ \\
\hline $10^{7} \mathrm{~A}^{\mathrm{c}}$ & $1.50 \pm 0.04 \mathrm{c}$ & $4.26 \pm 0.05 b$ \\
\hline $10^{8} \mathrm{~A}^{\mathrm{c}}$ & $1.48 \pm 0.11 \mathrm{c}$ & $3.77 \pm 0.12 \mathrm{c}$ \\
\hline $10^{7} \mathrm{I}^{\mathrm{c}}$ & $2.60 \pm 0.09 \mathrm{a}$ & $4.78 \pm 0.11 \mathrm{ab}$ \\
\hline $10^{8} \mathrm{I}^{\mathrm{e}}$ & $2.24 \pm 0.04 \mathrm{ab}$ & $5.84 \pm 0.13 a$ \\
\hline $10^{7} \mathrm{~A}+\mathrm{I}^{\mathrm{c}}$ & $2.73 \pm 0.03 \mathrm{a}$ & $5.29 \pm 0.12 \mathrm{ab}$ \\
\hline $10^{8} \mathrm{~A}+\mathrm{I}^{\mathrm{c}}$ & $2.23 \pm 0.05 b$ & $6.00 \pm 0.10 \mathrm{a}$ \\
\hline
\end{tabular}

${ }^{\mathrm{a}}$ The data were collected 7 or 14 days after inoculation for seedling stage and germination stage, respectively. Each trial was made with at least 10 seeds/seedlings and the trials were repeated at least 3 times.

b "Germination Stage" means that PBG_invit was inoculated to surface sterilized seeds whereas "Seedling Stage" means that PBG_invit was inoculated to 7 day-seedlings following in vitro germination.

${ }^{c}$ The different letters following the means showed the statistical difference compared to the LSD test following ANOVA $(\mathrm{P} \leq 0.05)$. Difference was evaluated vertically.

${ }^{\mathrm{d}}$ Mean \pm Standard Error; ${ }^{\mathrm{C}} \mathrm{A}$ : active form of bacterium; I: inactive form of bacterium; $\mathrm{A}+\mathrm{I}$ : active and inactive form of the bacterium.

Table 3. Influence of PGB_invit inoculation in different physiological stages on shoot length (SL in cm) of $A$. thaliana seedlings $s^{2}$

\begin{tabular}{|c|c|c|}
\hline $\begin{array}{l}\text { Inoculation } \\
(\mathrm{CFU} / \mathrm{ml})\end{array}$ & $\begin{array}{c}\text { Germination Stage } e^{\mathrm{b}, \mathrm{c}} \\
(\text { Mean } \pm \mathrm{SE})^{\mathrm{d}} \\
(\mathrm{mg})\end{array}$ & $\begin{array}{c}\text { Seedling Stage }^{\mathrm{b}, c} \\
(\text { Mean } \pm \text { SE })^{\mathrm{d}} \\
(\mathrm{mg})\end{array}$ \\
\hline Control & $0.39 \pm 0.03 c$ & $0.26 \pm 0.01 \mathrm{a}$ \\
\hline $10^{7} \mathrm{~A}^{\mathrm{c}}$ & $0.35 \pm 0.01 \mathrm{c}$ & $0.23 \pm 0.01 \mathrm{ab}$ \\
\hline $10^{8} \mathrm{~A}^{\mathrm{c}}$ & $0.25 \pm 0.01 \mathrm{~d}$ & $0.24 \pm 0.01 \mathrm{a}$ \\
\hline $10^{7} \mathrm{I}^{\mathrm{c}}$ & $0.48 \pm 0.02 b$ & $0.26 \pm 0.00 \mathrm{a}$ \\
\hline $10^{8} I^{e}$ & $0.37 \pm 0.00 \mathrm{c}$ & $0.20 \pm 0.00 \mathrm{~b}$ \\
\hline $10^{7} \mathrm{~A}+\mathrm{I}^{\mathrm{c}}$ & $0.39 \pm 0.01 \mathrm{c}$ & $0.26 \pm 0.01 \mathrm{a}$ \\
\hline $10^{8} \mathrm{~A}+\mathrm{I}^{\mathrm{c}}$ & $0.61 \pm 0.00 \mathrm{a}$ & $0.23 \pm 0.00 \mathrm{ab}$ \\
\hline
\end{tabular}

${ }^{a}$ The data were collected 7 or 14 days after inoculation for seedling stage and germination stage, respectively. Each trial was made with at least 10 seeds/seedlings and the trials were repeated at least 3 times.

b "Germination Stage" means that PBG_invit inoculation was made to surface sterilized seeds whereas "Seedling Stage" means that PBG_invit inoculation was made to 7 day-seedlings following in vitro germination.

'The different letters following the means show the statistical difference compared to the LSD test following ANOVA $(\mathrm{P} \leq 0.05)$. Difference was evaluated vertically.

${ }^{\mathrm{d}}$ Mean \pm Standard Error ; ${ }^{\mathrm{A}} \mathrm{A}$ : active form of bacterium; I: inactive form of bacterium; A+I: active and inactive form of the bacterium.

Table 4. Influence of PGB_invit inoculation in different physiological stages on root length ( $R L$ in $\mathrm{cm}$ ) of $A$. thaliana seedlings ${ }^{\mathrm{a}}$

\begin{tabular}{ccc}
\hline $\begin{array}{c}\text { Inoculation } \\
(\mathrm{CFU} / \mathrm{ml})\end{array}$ & $\begin{array}{c}\text { Germination Stage } \\
(\text { Mean } \pm \mathrm{SE})^{\mathrm{d}} \\
(\mathrm{mg})\end{array}$ & $\begin{array}{c}\text { Seedling Stage } \\
\left(\begin{array}{l}\text { (eean } \pm \mathrm{SE})^{\mathrm{d}} \\
(\mathrm{mg})\end{array}\right.\end{array}$ \\
\hline Control & $8.19 \pm 0.32 \mathrm{ab}$ & $7.80 \pm 0.04 \mathrm{~b}$ \\
$10^{7} \mathrm{~A}^{\mathrm{c}}$ & $8.13 \pm 0.23 \mathrm{a}$ & $7.01 \pm 0.20 \mathrm{c}$ \\
$10^{8} \mathrm{~A}^{\mathrm{c}}$ & $7.17 \pm 0.10 \mathrm{~b}$ & $6.84 \pm 0.21 \mathrm{c}$ \\
$110^{7} \mathrm{I}^{\mathrm{c}}$ & $7.52 \pm 0.15 \mathrm{~b}$ & $6.91 \pm 0.06 \mathrm{c}$ \\
$10^{8} \mathrm{I}^{\mathrm{c}}$ & $8.21 \pm 0.12 \mathrm{a}$ & $7.06 \pm 0.09 \mathrm{c}$ \\
$10^{7} \mathrm{~A}+\mathrm{I}^{\mathrm{c}}$ & $8.13 \pm 0.25 \mathrm{a}$ & $8.67 \pm 0.07 \mathrm{a}$ \\
$10^{8} \mathrm{~A}+\mathrm{I}^{\mathrm{c}}$ & $8.38 \pm 0.04 \mathrm{a}$ & $7.01 \pm 0.11 \mathrm{c}$ \\
\hline
\end{tabular}

$\bar{a}$ The data were collected 7 or 14 days after inoculation for seedling stage and germination stage, respectively. Each trial was made with at least 10 seeds/seedlings and the trials were repeated at least 3 times. "Germination Stage" means that PBG_invit inoculation was made to surface sterilized seeds whereas "Seedling Stage" means that PBG_invit inoculation was made to 7 day-seedlings following in vitro germination. ${ }^{\text {c The different letters }}$ following the means showed the statistical difference compared to the LSD test following ANOVA $(\mathrm{P} \leq 0.05)$. Difference was evaluated vertically. ${ }^{\mathrm{d}}$ Mean \pm Standard Error; ${ }^{\mathrm{C}} \mathrm{A}$ : active form of bacterium; I: inactive form of bacterium; $\mathrm{A}+\mathrm{I}$ : active and inactive form of the bacterium. 
958

Table 5. Influence of PGB_invit inoculation in different physiological stages on photosynthetic pigments of $A$. thaliana seedlings ${ }^{a}$

\begin{tabular}{|c|c|c|c|c|c|c|}
\hline \multirow{3}{*}{$\begin{array}{c}\text { Inoculation } \\
(\mathrm{CFU} / \mathrm{ml})\end{array}$} & \multicolumn{3}{|c|}{ Germination Stage $\mathrm{b}^{\mathrm{b}, \mathrm{c}}$} & \multicolumn{3}{|c|}{ Seedling Stage ${ }^{b, c}$} \\
\hline & $\mathrm{Chla}^{\mathrm{d}}$ & $\mathrm{Chlb}^{\mathrm{d}}$ & $\mathrm{Car}^{\mathrm{d}}$ & $\mathrm{Chla}^{\mathrm{d}}$ & $\mathrm{Chl} \mathrm{b}^{\mathrm{d}}$ & $\mathrm{Car}^{\mathrm{d}}$ \\
\hline & \multicolumn{3}{|c|}{$(\text { Mean } \pm S E)^{c}$} & \multicolumn{3}{|c|}{$(\text { Mean } \pm S E)^{e}$} \\
\hline Control & $110.57 \pm 9.81 \mathrm{~b}$ & $38.70 \pm 3.79 b$ & $35.90 \pm 2.44 \mathrm{~b}$ & $80.71 \pm 2.88 b$ & $30.60 \pm 3.46 b$ & $30.40 \pm 2.40 \mathrm{ab}$ \\
\hline $10^{7} \mathrm{~A}^{\mathrm{f}}$ & $202.8 \pm 17.25 a$ & $81.50 \pm 9.93 \mathrm{a}$ & $60.90 \pm 4.67 \mathrm{a}$ & $42.40 \pm 6.47 \mathrm{c}$ & $15.90 \pm 2.4 \mathrm{c}$ & $17.50 \pm 2.01 \mathrm{c}$ \\
\hline $10^{8} \mathrm{~A}^{\mathrm{f}}$ & $204.1 \pm 12.44 a$ & $85.40 \pm 6.68 \mathrm{a}$ & $61.10 \pm 3.24 a$ & $117.20 \pm 14.99 \mathrm{a}$ & $40.40 \pm 4.90 \mathrm{ab}$ & $36.80 \pm 3.43 a$ \\
\hline $10^{7} \mathrm{I}^{\mathrm{f}}$ & $75.05 \pm 4.23 b c$ & $33.20 \pm 1.71 b$ & $26.10 \pm 0.81 b$ & $85.10 \pm 13.63 \mathrm{ab}$ & $43.20 \pm 6.39 a$ & $25.60 \pm 3.73 b$ \\
\hline $10^{8} \mathrm{I}^{\mathrm{f}}$ & $88.68 \pm 8.68 \mathrm{bc}$ & $38.40 \pm 3.08 b$ & $30.00 \pm 2.09 b$ & $107.24 \pm 15.02 \mathrm{ab}$ & $12.06 \pm 4.92 \mathrm{c}$ & $28.50 \pm 4.26 \mathrm{ab}$ \\
\hline $10^{7} \mathrm{~A}+\mathrm{I}^{\mathrm{f}}$ & $60.40 \pm 5.84 c$ & $28.60 \pm 1.87 \mathrm{~b}$ & $23.80 \pm 1.44 \mathrm{~b}$ & $99.20 \pm 15.42 \mathrm{ab}$ & $30.70 \pm 3.07 \mathrm{bc}$ & $31.20 \pm 4.30 \mathrm{ab}$ \\
\hline $10^{8} \mathrm{~A}+\mathrm{I}^{\mathrm{f}}$ & $89.80 \pm 8.60 b c$ & $36.90 \pm 3.98 b$ & $31.40 \pm 2.59 \mathrm{~b}$ & $72.80 \pm 7.98 \mathrm{~b}$ & $24.70 \pm 2.77 \mathrm{c}$ & $26.40 \pm 2.26 b c$ \\
\hline
\end{tabular}

${ }^{\bar{a}}$ The data were collected 7 or 14 days after inoculation for seedling stage and germination stage, respectively. Each trial was made with at least 10 seeds/seedlings and the trials were repeated at least 3 times.

b "Germination Stage" means that PBG_invit inoculation was made to surface sterilized seeds whereas "Seedling Stage" means that PBG_invit inoculation was made to 7 day-seedlings following in vitro germination.

${ }^{c}$ The different letters following the means showed the statistical difference compared to the LSD test following ANOVA ( $\left.\leq 0.05\right)$. Difference was evaluated vertically.

${ }^{\mathrm{d}}$ Chl a: Chlorophyll A; Chl b: Chlorophyll B; Car: Caretonoids.

${ }^{\mathrm{c}}$ Mean \pm Standard Error.

${ }^{\mathrm{f}} \mathrm{A}$ : active form of bacterium; I: inactive form of bacterium; $\mathrm{A}+\mathrm{I}$ : active and inactive form of the bacterium.
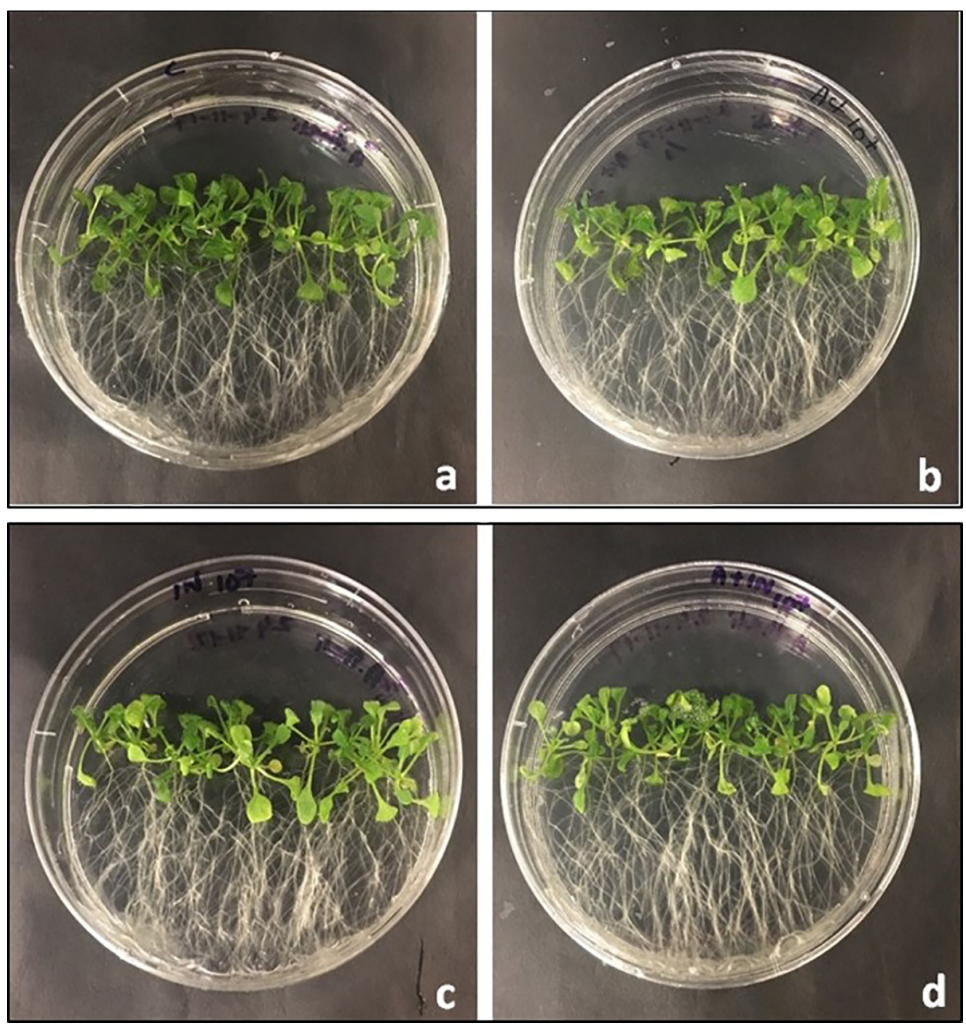

Fig. 1. Phenotypic results of $10^{7}$ inoculation of PGB_invit on 7 day-seedlings of $A$. thaliana after 14 days of culture. a) Control, b) A, c) I and d) A+ I

Molecular confirmation of endophytic and rbizopheric colonization of $P G B$ _invit in seedlings

The MPYE agar Petri plates with experimental inoculants incubated at $30^{\circ} \mathrm{C}$ were analyzed for endophytic and rhizospheric colonization of the bacterium. The presence of bacterium was evident in E1 and R1 inoculated plates thus verifying the interaction of PGB_invit with seedlings both endophytically and rhizospherically. As expected, no colony was formed on E2, E3, R2, R3 and sterilization control plates, indicating inactivation of bacteria (E2, R2). Gram staining results from both E1 and
R1 single colony staining showed the presence of Gram negative, non-motile bacterial cells existing singly or in pairs, which was in accordance with the characteristics of PGB_invit previously reported by Şeker et al. (2017).

Gel Electrophoresis of PCR amplified product obtained with virDI universal primers, showed the presence of 500 bp band from both endophytically and rhizospherically isolated bacterial cultures from the seedlings and from the isolated plasmid DNA of PGB_invit (Fig. 2). 


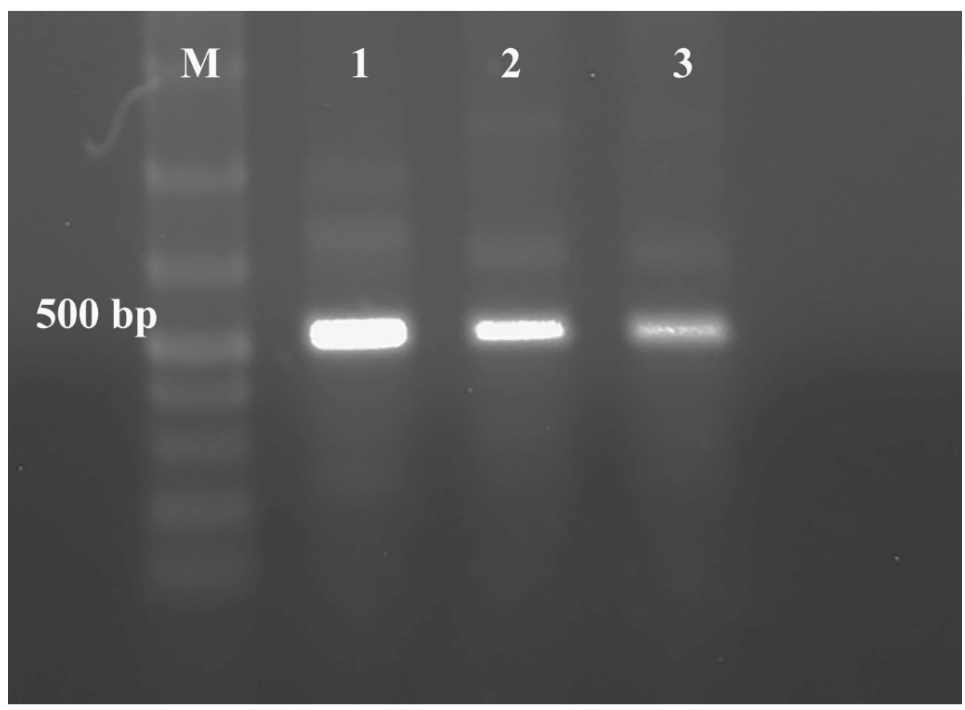

Fig. 2. PCR analysis of plasmid DNA of PGB_invit isolated from endophytic and rhizospheric samples of seedlings. Lane M; $1 \mathrm{~kb}$ Molecular weight marker, Lane 1; single colony culture, Lane 2; endophytically isolated plasmid DNA, Lane 3; rhizospherically isolated plasmid DNA

\section{Discussion}

A wide range of parameters were assessed in this study to reveal out the effect of different concentrations of PGB_invit on the growth and health of $A$. thaliana (Col-0) at two different physiological stages. Our results showed the effectiveness of I form of bacterium together with $\mathrm{A}+\mathrm{I}$ bacterial compositions on the plant growth. It was interesting to see that $\mathrm{I}$ and $\mathrm{A}+\mathrm{I}$ populations of $10^{7}$ caused an overall increase in FW of the 7-day inoculated seedlings while same results were observed for $10^{8}$ populations in case of DW. While A populations for both concentrations stayed behind for biomass, they positively affected chlorophyll contents of the seedlings.

For seed stage inoculations, I form of the bacterium did not evoke plant defense mechanisms as no decline or decrease in plant growth was observed, while A form alone stayed vulnerable to plant defense systems. Here, it is important to discuss about the difference of effects for two tested concentrations of bacterium populations. For instance, $\mathrm{I} 10^{7}$ and $10^{8}$ populations remained more or less positively affective towards all the parameters of the seedlings whether alone or co-cultivation with $\mathrm{A}$, while $\mathrm{A}$ populations $\left(10^{7}\right.$ and $\left.10^{8}\right)$ kept switching according to the biomass or photosynthetic content ratios and physiological stages of the seedlings.

The positive effects of I form of bacterium can be explained by predicting that cell wall of bacterium was perhaps some kind of hindrance towards direct interaction with plant surface for some of the remaining active cytoplasmic contents, such as certain root and shoot promoting phytohormonal substances. Inactivation might have caused these contents to come in direct contact with the plant surface, thus providing the results perceived. Therefore, it could be stated that I isolate was found positive or even much productive as compared to A for some PGP traits even after subjection to high temperature that partially inactivated the bacterium. High temperature tolerance of possibly growth promoting phytohormonal substances suggests that it can be thinkable to use inactivated form of this putative bacterium with compatible bio-inoculants (bio-fertilizers), but after a series of evaluations for different factors. In a similar kind of study, Nehra and co-workers (2016) evaluated Brevibacillus brevis as a potential plant growth promoting rhizobacteria for cotton (Gossypium birsutum) crop by treating with high temperatures $\left(46^{\circ} \mathrm{C}\right)$ and found that bacterium retained its positive activity. Our bacterium partially retained PGP activity as it was subjected to very high temperature $\left(95^{\circ} \mathrm{C}\right)$. Moreover, it even enhanced the positive effect of active bacterium on seedlings thus providing additive support towards growth promotion of plant overall. Therefore, in future, a temperature tolerance studies can be conducted in detail to learn the potential behavior of this bacterium towards PGP activities.

Increase in FW and DW refers to an increased cytokinins and auxins production since these phytohormones are essential for plant growth and development. These results coincide with the earlier findings for this putative endophytic bacterium (Şeker $e t$ al., 2017). These findings are also in conformity with the literature for PGPRs and endophytes as these are known to produce phytohormones for plant growth (Mendes et al., 2007). PGP-invit appeared to be involved in increasing biomass and it is therefore credible to think to use this bacterium with other compatible PGPRs or soil microbes for root biomass and chlorophyll contents in right composition for an overall increase in plant growth. Valdenegro et al. (2001) used a wide range of compatible strains including bacteria, fungi and mycorrhizae to enhance the overall growth of Medicago arborea in a semi-arid Mediterranean area.

Interestingly, A form of bacterium increased chlorophyll content in seed stage inoculation, which can be related to biomass vs photosynthetic content ratio (Zhang et al., 2008). In addition, for seedling stage inoculations, $A$ at $10^{8}$ caused an increase in photosynthetic contents, while less contributing towards seedling biomass. The increase in photosynthetic contents as compared to non-inoculated 
960

seeds can be related to regulatory role of plant symbionts as Zhang et al. (2008) suggested that Bacillus subtilis GB03 soil bacteria augment Arabidopsis photosynthesis by decreasing glucose sensing and abscisic acid levels. The accumulation of sugar content in roots or shoots might be considered as the reason of elevated sugar levels induces storage processes and confers feedback inhibition of photosynthesis and vice versa (Jang and Sheen, 1994; Sheen, 1994; Jang et al., 1997; Rook et al., 2001; Moore et al., 2003; Rolland et al., 2006). In this regard also, the I form of bacterium studies is very important because of its consistency towards plant growth promotion.

The reason why active populations didn't work well with seed stage inoculation might lies in the fact that seeds maintain their protective state until external environment conditions become favorable for their development process and after imbibition and embryo exposure, emerged seedling become even more sensitive to environmental conditions (Karssen, 1982; Pritchard et al., 1993; Bungard et al., 1997). While A form of bacterium possibly caused the activation of the seed and later the seedlings plant defense mechanisms, I form might have not activated these defense systems as it was not virtually alive. The same can also be considered true for seedling inoculations.

PCR amplification of plasmid DNA from PGB_invit as a template and using universal forward and reverse primers of virDl approved the presence of virDl gene on the plasmid of colonies in E1 and R1 plates, suggesting that PGB_invit depicts both rhizospheric and endophytic colonization in $A$. thaliana. In fact, the size of $\operatorname{vir} D 1$ gene (500 bp) is slightly different from $A$. rhizogenes virDl gene ( 450 bp), (Hamill et al., 1991) indicating the fact that the size of virD1 gene might be slightly longer in PGB_invit.

\section{Conclusions}

Overall findings demonstrate that PGB-invit shows both endophytic and rhizospheric colonization in $A$. thaliana and has beneficial impact when inoculated especially at seedling stage in optimum concentrations and conditions. Presence of virDl in this bacterium also depicts its possible potential to be used as plant biotechnological studies. However, it is still hard to provide any definitive statement regarding the behavior of PGB invit because of the complex nature of plant-microbe interactions. The positive influences of PGB_invit previously in fraser photinia and now $A$. thaliana suggests that this bacterium is possibly not host specific. In this regard, study of this bacterium against different potential hosts will be a handy approach to evaluate its potential as a possible PGPR near future. Moreover, the studies at molecular level for $A$. thaliana using molecular tools such as transcriptomics or microarrays will be quite useful to shed light on plant and bacterium interaction.

\section{Acknowledgements}

Authors would like to thank Dr. Doğa Selin Kayıhan for her help in providing $A$. thaliana (Col-0) seeds and photosynthesis pigment analysis.

\section{Conflicts of interest}

The authors declare that there are no conflicts of interest related to this article.

\section{References}

Bungard RA, Mcneil D, Morton J (1997). Effects of chilling, light and nitrogen-containing compounds on germinations, rate of germination and imbibition of Clematis vitalba L. Annals ofBotany 79(6):643-645.

Dunne C, Crowley JJ, Loccoz YM, Dowling DN, de Bruijn F, O'Gara F (1993). Biological control of Pythium ultimum by Stenotrophomonas maltophilia W81 is mediated by an extracellular proteolytic activity. Microbiology 143(12):3921-3931.

Farh ME-A, Kim Y-J, Sukweenadhi J,Singh P, Yang DC (2017). Aluminium resistant plant growth promoting bacteria induce overexpression of aluminium stress related genes in Arabidopsis thaliana and increase the ginseng tolerance against aluminium stress. Microbiological Research 200:45-52.

Glick BR (1995). The enhancement of plant growth by free-living bacteria. Canadian Journal of Microbiology 41(2):109-117.

Glick BR, Patten CL, Holguin G, Penros DM (1999). Biochemical and genetic mechanisms used by plant growth promoting bacteria. Imperial College Press, London, United Kingdom pp 267.

Şeker MG, Şah I, Kırdök E, Ekinci H, Çiftçi YÖ, Akkaya Ö (2017). A hidden plant growth promoting bacterium isolated from in vitro cultures of fraser photinia (Photinia $\times$ fraseri). International Journal of Agriculture and Biology 19(6):1511-1519.

Hallmann J, Berg G (2006). Spectrum and population dynamics of bacterial root endophytes. In: Schulz BJ (Ed). Microbial Root Endophytes. Springer-Verlag, Berlin pp 15-31.

Hamill JD, Rounsley S, Spencer A, Todd G, Rhodes MJ (1991). The use of the polymerase chain reaction in plant transformation studies. Plant Cell Reports 10(5):221-224.

Hardoim PR, van Overbeek LS, van Elsas JD (2008). Properties of bacterial endophytes and their proposed role in plant growth. Trends in Microbiology 16(10):463-471.

Ishiga Y, Ishiga T, Uppalapati SR, Mysore S (2011). Arabidopsis seedling flood-inoculation technique: a rapid and reliable assay for studying plantbacterial interactions. Plant Methods 7(1):32.

Jang JC, Sheen J (1994). Sugar sensing in higher plants. The Plant Cell 6(11):1665-1679.

Jang JC, Leon P, Zhou L, Sheen J (1997) Hexokinase as a sugar sensor in higher plants. The Plant Cell9(1):5-19.

Karssen CM (1982). Seasonal patterns of dormancy in weed seeds. In: Khan AA (Ed). The Physiology and Biochemistry of Seed Development, Dormancy and Germination. Elsevier Biomedical Press, Amsterdam Netherlands pp 243-270.

KloepperJW, Hume DJ, Scher FM, Singleton C, Tipping B, Laliberté M, ... Lee L (1988). Plant growth-promoting rhizobacteria on canola (rapeseed). Plant Disease 72(1):42-45.

Kloepper JW, Lifshitz R, Zablotowicz RM (1989). Free living bacterial inocula for enhancing crop productivity. Trends in Biotechnology $7(2): 39-44$. 
Lichtenthaler HK, Buschmann C (2001). Chlorophylls and carotenoids: Measurement and characterization by UV-VIS spectroscopy. Current Protocols Food Analytical Chemistry 1(1):F43.

Liu L, Kloepper JW, Tuzun S (1995). Induction of systemic resistance in cucumber against bacterial angular leaf spot by plant growth-promoting rhizobacteria. Phytopathology 85(8):843-847.

Mendes R, Pizzirani-Kleiner AA, Araujo WL, Raaijmakers JM (2007). Diversity of cultivated endophytic bacteria from sugarcane: genetic and biochemical characterization of Burkholderia cepacia complex isolates. Applied and Environmental Microbiology 73(22):7259-7267.

Moore B, Zhou L, Rolland F, Hall Q, Cheng WH, Liu YX, ... Sheen J (2003). Role of the Arabidopsis glucose sensor HXK1 in nutrient, light, and hormonal signaling. Science 300(5617):332-336.

Murashige T, Skoog F (1962). A revised medium for rapid growth and bioassays with tobacco tissue cultures. Physiologia Plantarum 15(3):473497.

Nehra V, Saharan BS, Choudhary M (2016). Evaluation of Brevibacillus brevis as a potential plant growth promoting rhizobacteria for cotton (Gossypium hirsutum) crop.Springer Plus 5(1):948.

Poupin MJ, Timmermann T, Vega A,Z Zuniga A, GonzalezB (2013).Effects of the plant growth-promoting bacterium Burkholderia phytofirmans PSIN throughout the life cycle of Arabidopsis thaliana. PLoS One $8(7): \mathrm{e} 69435$.

Pritchard HW, Wood JA, Mjanger KR (1993). Influence of temperature on seed germination and the nutritional requirements for embryo growth in Arum maculatum L. TheNew Phytologist 123(4):801-809.

Rolland F, Baena-Gonzalez E, Sheen J (2006). Sugar sensing and signaling in plants: conserved and novel mechanisms. Annual Review of Plant Biology 57:675-709.

RookF, Corke F, Card R, Munz G, Smith C, Bevan MW (2001). Impaired sucrose-induction mutants reveal the modulation of sugar-induced starch biosynthetic gene expression by abscisic acid signaling. The Plant Journal 26(4):421-433.
Rosenblueth M, Martinez-RomeroE (2006). Bacterial endophytes and their interactions with hosts. Molecular Plant-Microbe Interactions 19(8):827-837.

Ryan RP, Germaine K, Franks A, Ryan DJ, Dowling DN (2008). Bacterial endophytes: Recent developments and applications. FEMS MicrobiologyLetters 278(1):1-9.

Şah I (2017). Biochemical and molecular characterization of plant growth promoting putative endophytic bacterium isolated from in vitro cultures of Photinia $\times$ fraseri dress. $\mathrm{PhD}$ thesis, Gebze Technical University.

Sheen J (1994). Feedback control of gene expression. Photosynthesis Research 39(3):427-438.

Sukweenadhi J, Kim YJ, Choi ES, Koh SC, Lee SW, Kim YJ, Yand DC (2015). Paenibacillus yonginensis DCY84T induces changes in Arabidopsis thaliana gene expression against aluminum, drought, and salt stress. Microbiological Research 172:7-15.

Valdenegro M, Barea JM, Azcon R (2001). Influence of arbuscularmycorrhizal fungi, Rhizobium meliloti strains and PGPR inoculation on the growth of Medicago arborea used as model legume for re-vegetation and biological reactivation in a semi-arid Mediterranean area. Plant Growth Regulation 34(2):233-240.

Weller DM, Cook RJ (1986). Increased growth of wheat by seed treatments with fluorescent pseudomonads, and implications of Pythium control. Canadian Journal of Plant Pathology 8(3):328-334.

Zhang H, Xie X, Kim MS, Kornyeyev DA, Holaday S, Paré PW (2008). Soil bacteria augment Arabidopsis photosynthesis by decreasing glucose sensing and abscisic acid levels in planta. The Plant Journal 56(2):264 273. 